\title{
Evaluation of Integrated Nutrient Management Practices on Growth, Yield and Economics of Green Chilli cv Pusa Jwala (Capsicum annuum L.)
}

\author{
P. Leela Rani ${ }^{1 *}$, K. Balaswamy², A. Ramachandra Rao² and S. C. Masthan²
}

${ }^{1}$ AICRP on Weed Management, Dimond Jublee Block, College of Agriculture, ${ }^{2}$ Agriculture Research Institute, Professor Jayashankar Telangana State Agricultural University, Rajendranagar, Hyderabad, Telangana State (500 030), India

\section{Article History}

Manuscript No. AR839

Received in $8^{\text {th }}$ July, 2014

Received in revised form $15^{\text {th }}$ December, 2014

Accepted in final form $17^{\text {th }}$ January, 2015

\section{Correspondence to}

*E-mail: leelagro@gmail.com

\section{Keywords}

Green chilli, INM, growth, yield and economics

\begin{abstract}
The present study was carried out during 2007 and 2008 rabi season at Agricultural Research Institute, Rajendranagar, Hyderabad, Telangana state, India. with 9 treatment combinations (Recommended dose of inorganic fertilizer (200-60-80 kg NPK ha-1), $150 \%$ of RDNF, $200 \%$ of RDNF, $250 \%$ of RDNF, Complete organic N through FYM (25\%) and neem cake (25\%) as basal and vermicompost as top dressing (50\%), 50\% organic $+50 \%$ RDNF, $75 \%$ organic $+75 \%$ RDNF, $100 \%$ organic $+100 \%$ RDNF, $125 \%$ organic $+125 \%$ RDNF) in randomize block design with 3 replications. Combined application of $150 \mathrm{~kg} \mathrm{~N}^{-1}$ along with $10 \mathrm{t} \mathrm{FYM}$ and $0.5 \mathrm{t}$ neem cake ha ${ }^{-1}$ showed significant increase in plant height $(59,58 \mathrm{~cm})$, canopy spread $(40.7,42.1 \mathrm{~cm})$, number of branches plant ${ }^{-1}(23,23)$, number of fruits plant ${ }^{-1}(194,164)$, yield plant ${ }^{-1}(410,315$ g) and total green chilli yield of 13306 and $10550 \mathrm{~kg} \mathrm{ha}^{-1}$ respectively. But number of fruits plant ${ }^{-1}$, yield plant ${ }^{-1}$ and total yield ha ${ }^{-1}$ were on par with combined application of 100 and $125 \%$ organic manures and inorganic fertilizers each, respectively. However in terms of benefit cost ratio combined application of $150 \mathrm{~kg} \mathrm{~N} \mathrm{ha}^{-1}$ along with $10 \mathrm{t}$ FYM and 0.5 t neem cake was economical with highest net returns (₹ 79923 and ₹ $\left.52369 \mathrm{ha}^{-1}\right)$ and B:C (2.5 and 1.99). Significantly the lowest growth, yield attributes and fruit yield (1924 and $3577 \mathrm{~kg} \mathrm{ha}^{-1}$ ) of green chilli with negative net returns (₹ 45063 and $\left.₹ 28537 \mathrm{ha}^{-1}\right)$ and lower B C (0.3 and 0.56$)$ was noticed in complete organic manure application.
\end{abstract}

\section{Introduction}

Chilli (Capsicum annuum L.) is one of the important vegetable-cum-spice crops of India. It has different types of protein, vitamin, and ascorbic acid contents and is a good source of medicinal potential. The crop is very important for agricultural economy and is used in processing industries. India is the largest producer, consumer and exporter of chilli, which contribute to $25 \%$ of total world's production. In India, chilli is grown in almost all the states across the length and breadth of the country. In India the most important chilli growing states are Karnataka, Tamil Nadu, Orissa, Maharashtra, Rajasthan and West Bengal. Andhra Pradesh is the largest producer of chilli in India, contributes about $30 \%$ to the total area under chilli, followed by Karnataka (20\%), Maharashtra (15\%), Orissa (9\%), Tamil Nadu (8\%) and other states contributing $18 \%$ to the total area under chilli (Kumar, 2013). It is predominantly popular for its green pungent fruits, which is used for culinary purpose. Chilli production has to be increased primarily from enhancing the productivity with a combination of high yielding plant types (Paul et al., 2013), standard agronomic practices like seed priming (Maiti et al., 2013) and balanced plant nutrition attained through integrated nutrient management (INM). Since chemical fertilizer alone will not be able to sustain the productivity, integrated use of all potential sources of plant nutrients seems to be the only option to maintain soil fertility and crop productivity.

After the green revolution, increase in production was achieved at the cost of soil health. It has been proved that indiscriminate use of inorganic fertilizers results in decrease in soil fertility and increase in soil acidity with depletion of organic humus content in addition to poor crop quality. Use of organic manures to meet the nutrient requirements of crop would be an inevitable practice in the years to come for sustainable agriculture since organic manures not only improve the soil physical, chemical and biological properties (Heitkamp et al., 2011) but also improves the moisture holding 
capacity of soil, thus resulting in enhanced crop productivity along with better quality of crop produce (Premsekhar and Rajashree, 2009). Hence fertilizers, manures and other amendments either alone or in combinations could be used to develop nutrient supplying capacity of the soil (Dutta and Sangtam, 2014). The yield of chilli depends on adequate supply of the essential nutrients (Alabi, 2006). According to Stroehlein and Oebker, (1979) N application to chilli peppers showed a significant increase in plant growth characteristics, color and nutrient content of leaves and yield.

The growth parameters like plant height and number of branches plant ${ }^{-1}$ was found maximum with combined application of vermicompost and urea at 50\% level. The yield attributes including fruit yield was found maximum with nitrogen received from vermicompost and urea at 50\% level. Improvement in qualitative aspects was increased with the application of neem cake compared to other inorganic sources (Pariari and Khan, 2013).

Experimental findings of Jayanthi et al. (2014) showed positive influence on soil quality, yield and quality characters of chilli with combined application of vermi fertilizer along with recommended dose of chemical fertilizer (RDCF). Further, the vermi fertilizer reduces $50 \%$ of the RDCF to the crop and enhances the soil quality, yield and quality of chilli than chemical fertilizer alone. Further the combined use of organics (farmyard manure, vermicompost, biofertilizers, panchagavya) along with the inorganic fertilizers increased the nutrient use efficiency, apparent nutrient recovery and the available nutrient status of the soil (Naidu et al., 2009).

Chilli crop respond to addition of nutrients through FYM, green manuring and chemical fertilizers (Sharma and Rana, 1993). Particularly chilli needs heavy manuring for better plant growth and high yield. Use of judicious combinations of organic and inorganic fertilizer sources is essential not only to maintain the soil health but also sustain the productivity (Malewar et al., 1998).

Use of organic manures alone cannot fulfil the crop nutrients requirement. There is a proper ratio between the organic and chemical sources and it should be worked out to derive the best combination of the inputs for attaining quantity and quality in chilli. The integrated supply and use of plant nutrients from chemical fertilizers and organic manures has been shown to produce higher crop yields than when they are applied alone. Hence, an investigation was undertaken to study the effect of organic and inorganic sources of nutrients on growth, yield and economics of chilli in periurben areas to sustain the productivity.

\section{Materials and Methods}

The present investigation was carried out at Agriculture Research Institute, Rajendranagar, Professor Jayashankar Telangana State Agricultural University, Hyderabad, Telangana, having $17^{\circ} 19^{\prime} \mathrm{N}$ latitude, $78^{\circ} 23^{\prime} \mathrm{E}$ longitude and $542.3 \mathrm{~m}$ from above mean sea level for two consecutive seasons during rabi 2006-07 and 2007-08 on chilli cv. Pusa jwala with an objective to study the effect of organic and inorganic sources of fertilizer in different combination on its growth and fruit yield in Southern Telangana Zone. The experimental site was red sandy loam, low in available $\mathrm{N}\left(275.8 \mathrm{~kg} \mathrm{~N} \mathrm{ha}^{-1}\right)$ and high in available $\mathrm{P}_{2} \mathrm{O}_{5}\left(74.5 \mathrm{P}_{2} \mathrm{O}_{5} \mathrm{~kg} \mathrm{ha}^{-1}\right)$ and $\mathrm{K}_{2} \mathrm{O}\left(294.5 \mathrm{~kg} \mathrm{ha}^{-1}\right)$. The experiment was laid out in randomized block design with three replications comprised of 9 treatment combinations viz. $\mathrm{F}_{1}$ :Recommended dose of inorganic fertilizer $(200-60-80 \mathrm{~kg}$ NPK ha $\left.{ }^{-1}\right) ; \mathrm{F}_{2}: 150 \%$ of RDNF (300 $\left.\mathrm{kg} \mathrm{N} \mathrm{ha}^{-1}\right) ; \mathrm{F}_{3}: 200 \%$ of RDNF (400 kg N ha-1); $F_{4}: 250 \%$ of RDNF (500 $\mathrm{kg} \mathrm{N} \mathrm{ha}^{-1}$ ); $\mathrm{F}_{5}$ :Complete organic $\mathrm{N}$ through FYM (25\%), neem cake (25\%) as basal and vermicompost as top dressing (50\%); $\mathrm{F}_{6}: 50 \%$ organic (FYM $\left.10 \mathrm{t} \mathrm{ha}^{-1}\right)+50 \%$ RDNF $\left(100 \mathrm{~kg} \mathrm{~N} \mathrm{ha}^{-1}\right) ; \mathrm{F}_{7}: 75 \%$ organic (FYM 10 tha $^{-1}+$ neem cake 0.5 tha $\left.^{-1}\right)+75 \%$ RDNF $(150$ $\left.\mathrm{kg} \mathrm{N} \mathrm{ha}{ }^{-1}\right) ; \mathrm{F}_{8}: 100 \%$ organic (FYM $10 \mathrm{t} \mathrm{ha}^{-1}+$ neem cake $1.0 \mathrm{t}$ $\left.\mathrm{ha}^{-1}\right)+100 \%$ RDNF $\left(200 \mathrm{~kg} \mathrm{~N} \mathrm{ha}^{-1}\right) ; \mathrm{F}_{9}: 125 \%$ organic (FYM 10 $\mathrm{t} \mathrm{ha}^{-1}+$ neem cake $1.0 \mathrm{tha}^{-1}$ and vermisompost $\left.1.5 \mathrm{tha}^{-1}\right)+125 \%$ RDNF (250 kg N ha-1).

Organic manures were applied (on equal $\mathrm{N}$ basis) as per the treatment and incorporated into the soil before sowing. In complete organic treatment entire FYM $\left(10 \mathrm{t} \mathrm{ha}^{-1}\right)$ and neem cake $\left(1.0 \mathrm{t} \mathrm{ha}^{-1}\right)$ were applied as basal. Remaining $50 \%$ was applied through vermicompost $\left(6.2 \mathrm{t} \mathrm{ha}^{-1}\right)$ as top dressing. Recommended uniform dose of $60 \mathrm{~kg} \mathrm{P}_{2} \mathrm{O}_{5}, 20 \mathrm{~kg}$ $\mathrm{K}_{2} \mathrm{O}$ and and $25 \% \mathrm{~N} \mathrm{ha}^{-1}$ was applied at the time planting. Whereas remaining nitrogen and potassium was applied in three equal splits at 20 days interval. The seedlings were planted in the plots measuring $30 \mathrm{~m}^{2}$ with spacing of $60 \times 30$ $\mathrm{cm}^{2}$. Multiple pickings were taken from green chilli for six times. Immedietly after harvesting their fresh yield was recorded. The weight of each picking was added to get the total green chilli yield. Observations were recorded on plant height $(\mathrm{cm})$, canopy spread $(\mathrm{cm})$, no. of branches plant ${ }^{-1}$, yield plant ${ }^{-1}(\mathrm{~g})$, no. of fruits plant ${ }^{-1}$, fruit wt $(\mathrm{g})$ and pod yield $\mathrm{kg} \mathrm{ha}^{-1}$ and were analyzed statistically as Gomez ${ }^{-1}$ and Gomez (1984).

The required amount of $\mathrm{N}, \mathrm{P}$ and $\mathrm{K}$ fertilizers was applied through urea, DAP and muriate of potash, respectively. Other cultural operations and plant protection measures were followed as per the recommendations. Crop received $941 \mathrm{~mm}$ (48 
rainy days) and $525.5 \mathrm{~mm}$ (41 rainy days) rainfall during the crop growth period in 2007 and 2008, respectively.

\section{Results and Discussion}

\subsection{Green chilli yield in relation to growth parameters and yield attributes}

Integrated nutrient management practices exerted significant influence on growth parameters like plant height $(\mathrm{cm})$, canopy spread $(\mathrm{cm})$, no. of branches plant ${ }^{-1}$ during both the years of investigation. During the first year of study significant increase in plant height $(59 \mathrm{~cm})$, canopy spread $(38.3 \mathrm{~cm})$ and branches (22) plant $^{-1}$ was observed with combined application of $75 \%$ through organics (FYM $10 \mathrm{t} \mathrm{ha}^{-1}+$ Neem cake $0.5 \mathrm{t} \mathrm{ha}^{-1}$ ) and $75 \%$ through inorganics ie RDNF $\left(\mathrm{F}_{7}\right)$ and it was on par with that of inorganic fertilizer application alone ie 150, 200 and $250 \%$ of RDNF and combined application of $50,100,125 \%$ organic and inorganic RDNF each. However, significantly the lowest plant height $(40 \mathrm{~cm})$, canopy spread $(25.7 \mathrm{~cm})$, no. of branches plant ${ }^{-1}$ (14) was observed with complete organic manure application. But during second year of investigation similar significant increase in plant height $(58 \mathrm{~cm})$ was observed with $75 \%$ organic and $75 \%$ inorganic RDNF application and was on par with that of all other treatments tried under study but significantly the lowest plant height $(47 \mathrm{~cm})$ was observed with complete organic manure application. Regarding canopy spread $(\mathrm{cm})$, no. of branches plant ${ }^{-1}$, combined application of $75 \%$ through organics (FYM $10 \mathrm{t} \mathrm{ha}^{-1}+\mathrm{Neem}$ cake $0.5 \mathrm{tha}^{-1}$ ) and $75 \%$ through inorganics ie RDNF recorded the significantly more spread $(42.1 \mathrm{~cm})$ and branches $(23)$ and was on par with combined application of $100,125 \%$ organic $+100,125 \%$ inorganic RDNF, but it was significantly different from remaining other treatments with the lowest canopy spread and branches from complete organic manure application. The increase in growth parameters such as plant height, canopy width and number of branches may be due to the application of organic manure which facilitates quick and greater availability of plant nutrients and thus provides a better environment for root growth and proliferation. It also creates more adsorptive surface for uptake of nutrients. These results are in accordance with the findings of Damke et al. (1988), who reported increased plant height and number of branches plant $^{-1}$ in chilli due to combined application of organic and inorganic fertilizers and also significant improvement in soil properties. The similar results were reported by siddesh (2006) in chilli from Karnataka.

During both years of study fruit yield per ha showed highly significant variation among the treatments. Yield increase (13306 and $10550 \mathrm{~kg} \mathrm{ha}^{-1}$ ) was observed with combined application of $75 \%$ through organics (FYM $10 \mathrm{t} \mathrm{ha}^{-1}+$ Neem cake $0.5 \mathrm{t} \mathrm{ha}^{-1}$ ) and $75 \%$ through inorganics ie RDNF and was significantly superior to 100,150, 200, $250 \mathrm{~kg}$ RDFN alone, combination of $50 \%$ organic and $50 \%$ inorganic and complete organic manure application (Table 1). However, inturn $\mathrm{F}_{7}$ treatment was on par with $\mathrm{F}_{8}$ treatment (100\% organic $\left.+100 \% \mathrm{RDNF}\right)$ and $\mathrm{F}_{9}$ $\left(125 \%\right.$ organic $+125 \%$ RDNF). The increased yield in $F_{7}$ was due to significantly more number of fruits plant ${ }^{-1}$ (194 and 164) and fruit weight plant ${ }^{-1}$ (410 and $315 \mathrm{~g}$ ) respectively. These parameters also showed the similar trend as that of final green fruit yield. The lowest yield and number of fruits plant ${ }^{-1}$ and fruit weight plant ${ }^{-1}$ was noticed with complete organic manure application alone. Increase in number of fruits plant $^{-1}$ is due to production of more number of flowers, higher percentage

\begin{tabular}{|c|c|c|c|c|c|c|c|c|c|c|c|c|c|c|}
\hline \multirow[t]{2}{*}{ Treatment } & \multicolumn{2}{|c|}{$\begin{array}{l}\text { Plant } \\
\text { height } \\
(\mathrm{cm})\end{array}$} & \multicolumn{2}{|c|}{$\begin{array}{c}\text { Canopy } \\
\text { width } \\
(\mathrm{cm})\end{array}$} & \multicolumn{2}{|c|}{$\begin{array}{c}\text { No. of } \\
\text { branches } \\
\text { plant }^{-1}\end{array}$} & \multicolumn{2}{|c|}{$\begin{array}{l}\text { No. of } \\
\text { fruits } \\
\text { plant }^{-1}\end{array}$} & \multicolumn{2}{|c|}{$\begin{array}{c}\text { Yield } \\
\text { plant }^{-1} \\
(\mathrm{~g})\end{array}$} & \multicolumn{2}{|c|}{$\begin{array}{l}\text { Fruit wt. } \\
(\mathrm{g})\end{array}$} & \multicolumn{2}{|c|}{$\begin{array}{c}\text { Total yield } \\
\mathrm{kg} \mathrm{ha}^{-1}\end{array}$} \\
\hline & 2007 & 2008 & 2007 & 2008 & 2007 & 2008 & 2007 & 2008 & 2007 & 2008 & 2007 & 2008 & 2007 & 2008 \\
\hline $100 \%$ RDNF & 48 & 56 & 35.7 & 37.6 & 19 & 20 & 104 & 91 & 209 & 192 & 2.02 & 2.1 & 7887 & 7677 \\
\hline $150 \%$ RDNF & 51 & 56 & 35.7 & 38.0 & 20 & 20 & 122 & 101 & 253 & 217 & 2.18 & 2.2 & 8194 & 9168 \\
\hline $200 \%$ RDNF & 52 & 56 & 39.7 & 38.8 & 21 & 21 & 155 & 111 & 328 & 244 & 2.04 & 2.2 & 9277 & 9620 \\
\hline $250 \%$ RDNF & 51 & 56 & 42.0 & 39.6 & 22 & 21 & 163 & 120 & 357 & 254 & 2.08 & 2.2 & 9899 & 9745 \\
\hline Organic & 40 & 47 & 25.7 & 31.5 & 14 & 16 & 76 & 46 & 67 & 89 & 0.86 & 1.9 & 1924 & 3577 \\
\hline $50 \%$ Organic $+50 \%$ Inorganic & 55 & 54 & 38.3 & 39.8 & 22 & 20 & 144 & 104 & 291 & 235 & 2.03 & 2.2 & 8991 & 9455 \\
\hline $75 \%$ Organic $+75 \%$ Inorganic & 59 & 58 & 40.7 & 42.1 & 23 & 23 & 194 & 164 & 410 & 315 & 2.17 & 1.9 & 13306 & 10550 \\
\hline $100 \%$ Organic $+100 \%$ Inorganic & 54 & 57 & 40.3 & 40.5 & 22 & 22 & 183 & 150 & 385 & 268 & 2.16 & 2.0 & 12546 & 10225 \\
\hline $125 \%$ Organic $+125 \%$ Inorganic & 53 & 56 & 41.0 & 40.2 & 23 & 21 & 180 & 148 & 374 & 259 & 2.13 & 1.9 & 12398 & 10051 \\
\hline $\mathrm{SEm} \pm$ & 2.99 & 1.5 & 2.27 & 1.0 & 1.73 & 0.8 & 5.32 & 8.8 & 12.63 & 27.9 & 0.06 & 0.1 & 314.5 & 345.3 \\
\hline $\mathrm{CD}(p=0.05)$ & 9.0 & 3.2 & 9.80 & 2.1 & 5.19 & 1.7 & 15.94 & 18.7 & 37.86 & 59.1 & 0.18 & NS & 943 & 732 \\
\hline
\end{tabular}


of fruit set and reduced shedding of flowers and fruits and resulted in increased fruits. The results of present investigation are conformity with the findings of Maurya and Lal (1987) and Balaraj (1999) in Chilli.

Among the treatments significantly the lowest fruit weight plant $^{-1}$ was observed in complete organic manure application during first year of study, however in second year treatments did not show any significant difference among themselves. Similar increase in fruit yield was observed in gangetic alluvial plain soils with 50\% nitrogen received from vermicompost and 50\% from urea (Pariari and Khan, 2013). The reasons for increased fruit yield in chilli was attributed to the increased solubilization effect and availability of nutrients by the addition of FYM and increased physiological activity leading to the build-up of sufficient food reserves for the developing sinks and better portioning towards the developing fruits. Similar results were also reported by Subbaiah et al. (1982) in Chilli. In the present study increase in growth and morphological parameters in the early stages of crop growth, indicate the efficiency of the plant to trap the available solar radiation efficiently which resulted in the increased rates of assimilates which inturn used in the fruit formation, thus ultimately increased the yield per unit area. The results of the present investigation are in conformity with the findings of Swamy and Subba Rao (1992).

Significant difference was not existed among the treatments with respect to available nitrogen, phosphorus and potassium status of the soil by the addition of organic and inorganic sources of nutrients (Table 3). The availability of nitrogen, phosphorus in the soil after the harvest of the crop was decreased, but increase in potassium availability was observed. The increased available potassium under organics application was as a result of additional $\mathrm{K}$ supplied through it, besides the solubulising action of certain organic acids produced during decomposition and its greater capacity to hold $\mathrm{K}$ in available form in soil and also due to the interaction of organic matter with clay and direct addition of potassium to the available pool of soil. Similar beneficial effects of organic manures on the available potassium content of soil were reported earlier in case of vermicompost (Pawar, 1996). Chilli requires major nutrients and micronutrients and role of $\mathrm{N}, \mathrm{P}$ and $\mathrm{K}$ in improving the productivity and quality has been reported by Nair and Peter (1990). Among the major nutrients, P and K are known to influence quality aspects and the $\mathrm{N}$ is better utilized only in the presence of $\mathrm{P}$ and $\mathrm{K}$. When the organics were added to soil, even though the initial available nitrogen content was low, the complex nitrogenous compounds slowly break down and make steady $\mathrm{N}$ supply throughout the growth period of the crop. This might have attributed to more availability and subsequent uptake by the crop, thus increasing the yield.

\section{Economics}

During two years of investigation significantly higher gross returns (₹ 133058 and ₹ 105504), net returns (₹ 79923 and $₹ 52369)$ and $\mathrm{BC}$ ratio (2.5 and 2.0) was obtained with combined application of 75\% through organics (FYM $10 \mathrm{t}$ $\mathrm{ha}^{-1}+$ Neem cake $0.5 \mathrm{t} \mathrm{ha}^{-1}$ ) and $75 \%$ through inorganics ie RDNF respectively. Negative net returns (₹ 45063 and ₹ 28537) were obtained for two consecutive years with complete organic manure application (Table 2). This might be due to lower yield and higher cost of cultivation compared to other treatments.

\begin{tabular}{|c|c|c|c|c|c|c|c|c|c|}
\hline & \multirow[t]{2}{*}{$\begin{array}{l}\text { Cost of culti- } \\
\text { vation ₹ ha }\end{array}$} & \multicolumn{2}{|c|}{$\begin{array}{l}\text { Total yield } \\
\mathrm{kg} \mathrm{ha}^{-1}\end{array}$} & \multicolumn{2}{|c|}{$\begin{array}{c}\text { Gross returns } \\
₹ \mathrm{ha}^{-1}\end{array}$} & \multicolumn{2}{|c|}{$\begin{array}{l}\text { Net returns } \\
₹ \text { ha }^{-1}\end{array}$} & \multicolumn{2}{|c|}{$\mathrm{B}: \mathrm{C}$ ratio } \\
\hline & & $\begin{array}{c}2006- \\
07\end{array}$ & $\begin{array}{c}2007- \\
08\end{array}$ & $\begin{array}{c}2006- \\
07\end{array}$ & $\begin{array}{c}2007- \\
08\end{array}$ & $\begin{array}{c}2006- \\
07\end{array}$ & $\begin{array}{c}2007- \\
08\end{array}$ & $\begin{array}{c}2006- \\
07\end{array}$ & $\begin{array}{l}2007- \\
08\end{array}$ \\
\hline $\mathrm{F}_{1} \quad 100 \% \mathrm{RDNF}$ & 48885 & 7887 & 7677 & 78871 & 76767 & 29986 & 27882 & 1.61 & 1.57 \\
\hline $\mathrm{F}_{2} \quad 150 \% \mathrm{RDNF}$ & 49985 & 8194 & 9168 & 81943 & 91676 & 31958 & 41691 & 1.64 & 1.83 \\
\hline $\mathrm{F}_{3} \quad 200 \% \mathrm{RDNF}$ & 51085 & 9277 & 9620 & 92769 & 96203 & 41684 & 45118 & 1.82 & 1.88 \\
\hline $\mathrm{F}_{4} \quad 250 \% \mathrm{RDNF}$ & 53185 & 9899 & 9745 & 98988 & 97450 & 45803 & 44265 & 1.86 & 1.83 \\
\hline $\mathrm{F}_{5}^{4}$ Organic & 64305 & 1924 & 3577 & 19242 & 35768 & -45063 & -28537 & 0.3 & 0.56 \\
\hline $\mathrm{F}_{6} \quad 50 \%$ Organic $+50 \%$ Inorganic & 50585 & 8991 & 9455 & 89915 & 94553 & 39330 & 43968 & 1.78 & 1.87 \\
\hline $\mathrm{F}_{7} \quad 75 \%$ Organic $+75 \%$ Inorganic & 53135 & 13306 & 10550 & 133058 & 105504 & 79923 & 52369 & 2.5 & 1.99 \\
\hline $\mathrm{F}_{8} \quad 100 \%$ Organic $+100 \%$ Inorganic & 55685 & 12546 & 10225 & 125457 & 102255 & 69772 & 46570 & 2.25 & 1.84 \\
\hline $\mathrm{F}_{9} \quad 125 \%$ Organic $+125 \%$ Inorganic & 59360 & 12398 & 10051 & 123976 & 100510 & 64616 & 41150 & 2.09 & 1.69 \\
\hline $\mathrm{SEm} \pm$ & & 314.5 & 345.3 & & & 3145.5 & 3452 & & \\
\hline $\mathrm{CD}(p=0.05)$ & & 943 & 732.0 & & & 9429 & 4882 & & \\
\hline
\end{tabular}




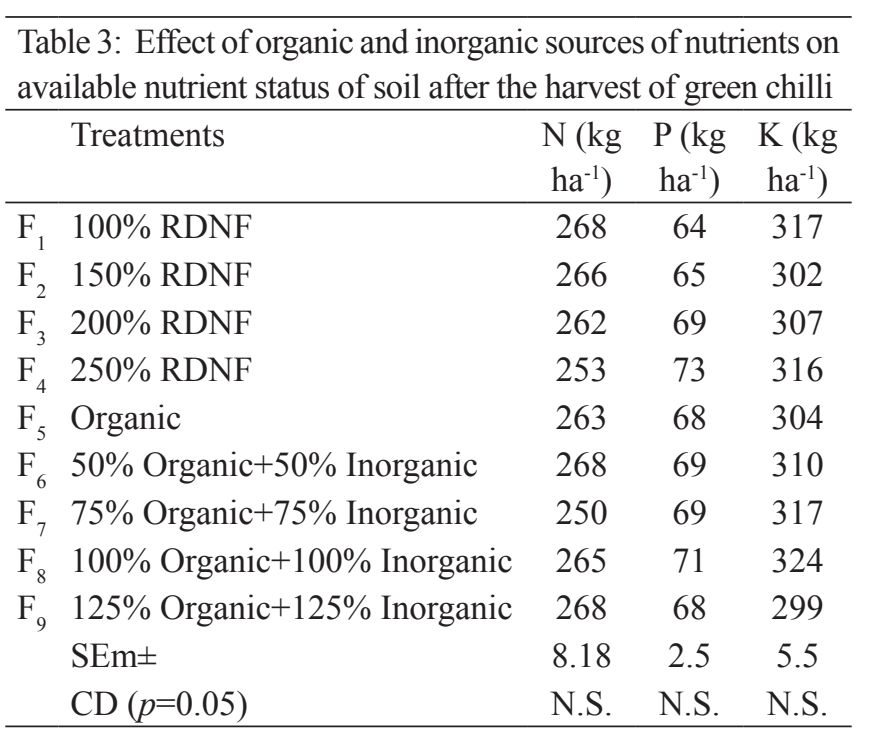

\section{Conclusions}

Combined application of FYM $10 \mathrm{tha}^{-1}+$ Neem cake $0.5 \mathrm{t} \mathrm{ha}^{-1}$ along with $150-60-80 \mathrm{~kg} \mathrm{~N} \mathrm{P} \mathrm{K} \mathrm{ha-1}$ was economical to get higher green chilli yield, net returns and $\mathrm{BC}$ ratio.

\section{References}

Alabi, D.A., 2006. Effects of fertilizer phosphorus and poultry droppings treatments on growth and nutrient components of pepper (Capsicum annuum L). African Journal of Biotechnology 5, 671-677.

Balaraj, R., 1999. Investigations of seed technological aspects in chilli (Capsicum annuum L.). Thesis submitted to the University of Agricultural Sciences, Dharwad.

Damke, M.M., Kawarkhe, V.J., Patil, C.O., 1988. Effect of phosphorus and potassium on growth and yield of chilli. Punjabrao Krishi Vidyapeeth Research Journal 112, 110-114.

Dutta, M., Sangtam, R., 2014. Integrated Nutrient Management on Performance of Rice in Terraced Land. International Journal of Bio-resource and Stress Management 5, 107-112.

Gomez, K.A., Gomez, A.A., 1984. Statistical Procedure for Agricultural Research, $2^{\text {nd }}$ Ed. John Wiley and Som Pub. Wiley, New York, 680.

Heitkamp, F., Raupp, J., Ludwig, B., 2011. Soil organic matter pools and crop yields as affected by the rate of farmyard manure and use of biodynamic preparations in a sandy soil. Organic Agriculture 1, 11-124.

Jayanthi, L., Sekar, J., Ameer Basha, S., Parthasarathi, K., 2014. Influence of Vermifertilizer on Soil Quality, Yield and Quality of Chilli, Capsicum annuum. International Inter disciplinary Research Journal 4, 204-217.

Kumar, A.K., 2013. Effect of foliar application of NPK nutrients on growth and yield of chilli (Capsicum annuum
L.). The Journal of Research. Acharya N.G. Ranga Agricultural University 41, 1-4.

Maiti, R., Rajkumar, D., Jagan, M., Pramani, K., 2013. Effect of Seed Priming on Seedling Vigour and Yield of Tomato and Chilli. International Journal of Bio-resource and Stress Management 4, 119-125.

Malewar, G.U., Syed, I., Rudraksha, G.B., 1998. Integrated Nitrogen Management in chilli (Capsicum annuum L.). Bulletin of Indian Institute of Soil Science 2, 156-163.

Maurya, C.P., Lal, H., 1987. Effect of IAA, NAA and GA on growth and yield of onion (Allium cepa $\mathrm{L}$.) and vegetable chilli (Capsicum annuum L.). Progressive Horticulture, 19, 203-206.

Naidu, D.K., Radder, B.M., Patil, P.L., Hebsur, N.S., Alagundagi, S.C., 2009. Effect of integrated nutrient management on nutrient uptake and residual fertility of chilli (Cv. byadgidabbi) in a vertisol. Karnataka Journal of Agricultural Sciences 22(2), 306-309.

Nair, M., Peter, K.V., 1990, Organic, inorganic fertilizers and thein combinations on yield and storage life of hot chilli. Vegetable Science 17, 7- 10.

Pariari, A., khan, S., 2013. Integrated nutrient management of chilli (Capsicum annuum L.) in Gangetic alluvial plains. Journal of Crop and Weed 9(2), 128-130.

Paul, S., Das, A., Sarkar, N.C., Ghosh, B., 2013. Collection of Chilli Genetic Resources from different Geographical Regions of West Bengal, India. International Journal of Bio-resource and Stress Management 4, 147-153.

Pawar, R.B., 1996, Dynamics of earth worms-soil plant relationship in semi-arid-tropics. Ph.D. Thesis, Univ. Agric. Sci., Dharwad (India).

Premsekhar, M., Rajashree, V., 2009. Influence of organic manures on growth, yield and quality of Okra. AmericanEurasian Journal of Sustainable Agriculture 3(1), 6-8.

Sharma, R.P., Rana, D.S.,1993. Nutrient management in vegetable crops. Fertilizer news., 45(4), 77-81.

Siddesh, H.K., 2006. Studies on integrated nutrient management on seed yield and quality of Chilli. Thesis submitted to the University of Agricultural Sciences, Dharwad.

Stroehlein, J.L., Oebker, N.F., 1979. Effects of nitrogen and phosphorus on yields and tissue analysis of chili peppers. Journal of American Society of Horticultural Sciences 114, 559-563.

Subbaiah, K., Helkiah, J., Ravi kumar, V., Rajagopal, 1982. Effect of combined application of organic and inorganic fertilizers on the yield and nutrient uptake of MDV chilli. South Indian Horticulture 30, 45-47.

Swamy, N.R., Subbarao, I.V., 1992. Physiological analysis of growth and yield in chilli under rainfed conditions. Haryana Journal of Horticultural Sciences 21, 247-250. 